\title{
Population Migration and The Challenges of Economic Growth in North Sumatera in Year (1988-2020)
}

\author{
Zulkarnain Nasution, Muhammad Ali Al Ihsan \\ Labuhanbatu University \\ Email: zulkarnainnasution1974@gmail.com and maaihsan@gmail.com
}

\begin{tabular}{|c|c|}
\hline ARTICLE INFO & ABSTRACT \\
\hline $\begin{array}{l}\text { Date received : } 03 \text { January } 2021 \\
\text { Revision date : } 02 \text { February } 2021 \\
\text { Date received : } 01 \text { March } 2021\end{array}$ & \multirow[b]{2}{*}{$\begin{array}{l}\text { Population increase has the impact on demographic transition } \\
\text { (changes in population structure). Indonesia is entering the } \\
\text { demographic bonus period, there is the increase in the } \\
\text { percentage of the working age population. According to } \\
\text { theory, population can affect economic growth (in this study } \\
\text { the effect on gross domestic product or GDP). One of the } \\
\text { demographic components that affect population composition } \\
\text { is population mobility or migration. This study used } \\
\text { migration, risk migration and dependency ratios to show the } \\
\text { latest patterns / trends of population mobility (last } 20 \text { years). } \\
\text { The results showed that the variables in this study had a } \\
\text { positive and negative effect on GDP growth. Of the three } \\
\text { variables, the greatest influence is given by percentage of } \\
\text { dependency ratio variable. The results of this study showed } \\
\text { that migration and risk migration had negative impact on } \\
\text { economic growth while the dependency ratio had a positive } \\
\text { impact on economic growth. North Sumatra must be } \\
\text { optimistic to increase economic growth by utilizing } \\
\text { components that can boost the economy and one of them is } \\
\text { the dependency ratio. }\end{array}$} \\
\hline $\begin{array}{l}\text { Keywords: } \\
\text { Migration } \\
\text { Recent Migration } \\
\text { Recent Worker } \\
\text { Dependency Ratio } \\
\text { Economic Growth }\end{array}$ & \\
\hline
\end{tabular}

\section{INTRODUCTION}

Indonesia has many natural and human resources. Existing human resources must be managed properly to optimize the natural resources owned. "Kuznets (1967) states that modern economic growth does not only focus on per capita income but also on population problems (human resources)".

Creative and productive human resources will increase the production of goods and services so that the economy will increase. In addition, human resources are also capable of developing knowledge and technology in optimizing limited natural resources.
In 2018, Indonesia was nominated as 4th largest population in the world after the People Republic of China, India and the United States. The population of Indonesia reaches 269.6 million in 2020 and based on the projection figures of the Central Statistics Agency (BPS) this number will continue to increase every year. A large total population becomes challenge and an opportunity for Indonesia. Viewed from the population growth rate, the 2015-2020 period Indonesia experienced a growth of 1.12 percent. Indonesia success in suppressing the birth rate is illustrated by the population dependency ratio which continues to decline.

\begin{tabular}{ll}
\hline How to cite: & $\begin{array}{l}\text { Nasution, Zulkarnain and Muhammad Ali Al Ihsan (2021) Population Migration and The } \\
\text { Challenges of Economic Growth in North Sumatera in Year (1988-2020) 2(3). } \\
\text { https://doi.org/10.46799/jsss.v2i3.137 }\end{array}$ \\
\hline E-ISSN: & $2721-5202$ \\
\hline Published by: & Ridwan Institute \\
\hline
\end{tabular}


The decreasing population dependency ratio shows that Indonesia has demographic potential or opens a demographic window of opportunity. "According to Peng \& Cheng (2005) the window of economic growth opens when the total population of young and old ages decreases". Opportunities can be obtained if the state already has investment, not only in family programs but also in general health and education, as well as job opportunities for new workers and unemployed.

The current pattern of population mobility in Indonesia can be seen from risky migration level. According to BPS (2017), recent migration is the movement of people from a place, in this case the province, the place they lived 5 years ago is different from their current residence. This indicator describes the level of dependence of the population. The rate of migration will affect the composition of the population of the migration destination, both in terms of age and sex. Population composition change, one of which is influenced by the characteristics of the perpetrators of migration (migrants) will also affect the opportunities of a region to enjoy opportunities for economic growth.

Based on data from the 2016 National

Socio-Economic Survey (Susenas), the number of migrant workers in Indonesia in 2016 was 4,450,336 people. Viewed from the age composition, most of the migrant workers were of productive age, the largest percentage was in the 20-29 year age group, namely 38.25 . The trend of recent migration during 2015 - 2016 tended to increase, in 2015 the proportion of population 5 years and over who undertook a risk migration was 1.82 percent and in 2016 increased to 1.89 percent. The results of the 2016 Labor Force Survey (Sakernas) also describe the condition of the migrant population in terms of employment. During that period, there were $2,396,045$ recent migrants or 53.84 percent of the total population of recent migrants and 64.04 percent of them were married. It shows that most of the recent migrants have economic motives towards the destination area. "Mettler, Massey, \& Kellman (2016) explain the theory of new economics of migration in which the decision to migrate is not only to maximize income as adopted by neoclassical economic theory". Migration is also a household decision to reduce the risk of obtaining minimal income and overcome capital constraints in household production activities. Decision to migrate is not a decision of an individual alone but rather a broad institutional unit such as the household and family.

"Todaro \& Smith (2012) states that migration flows take place in response to differences in income between areas of origin and destination. Revenue is the expected income, not actual income".

"According to Mantra (2000), Migration is the movement of a population that crosses the boundaries of their original territory to their destination with a permanent intention". On the other hand, non-permanent population migration is the movement of the population from one area to another with no intention of settling in the destination area. Meanwhile, according to Steele (Mantra, 2000), if a person moves to another area and intended not to stay in the destination area, the person is classified as a non-permanent migrant actor even though he resides the destination area for a long time.

The large number of resign workersbecomes the big capital for Indonesia to improve labor and economic conditions. The government must pay special attention to resign workersin Indonesia both in quantity and quality. Population migration does not add to the economic burden of the destination region but becomes an opportunity for economic growth so that it can support the economy of the migration destination areas and also contribute to income for the regions of origin of migrants in Indonesia. recent migrants, especially resign workers, as a form of population mobility, and it is expected to be able to equalize opportunities throughout all regions in Indonesia to enjoy opportunities to increase economic growth.

The availability of job opportunities is also related to investment in Indonesia. This incoming investment can become new employment opportunities for the productive 
age workforce during times of economic growth. So that the government tries to get much investment.

In several developing countries in East Asia, it is proved that the migration transitions from 1965 to 1990 have led to miraculous economic growth. It is due to the high growth of the working age population (Bloom \& Williamson, 1998). In addition, the demographic transition in developing countries Thailand has been shown to increase the workforce which in turn will increase economic growth through a window of opportunity (Bloom, Canning, \& Sevilla, 2004). Likewise, economic growth in South Korea has stimulated its economic growth to be the fastest with an average of four percent perYear. In addition, a decrease in the birth rate and an increase in the proportion of the working age population in China has been shown to increase its GDP per capita (Liu, Liu, \& Liu, 2013). GRDP per capita in India and Pakistan is also positively related to the growth in the proportion of the working age population and negatively related to the dependency burden rate (Choudhry \& Elhorst, 2010). In addition to the research results which state that economic growth has a positive effect on economic growth as described above, there are several other studies that economic growth does not have a significant effect on the economic growth of a country. It is illustrated by the results of research that the working age population in China has a negative impact on the growth of GDP per capita of the country and that economic growth has no impact on economic growth in China during 1989-2004 (Golley \& Zheng, 2015). In fact, this demographic transition has a negative relationship with economic growth in the Chinese country (Choudhry \& Elhorst, 2010).

By looking at the results of the study above, it is important to observe the drivers of economic growth in Indonesia. This study aimed to analyze economic growth, in this case is described in the ratio of dependence on the level of investment in Indonesia to economic growth, which is described by the Gross Domestic Product (GDP / GDP) data.
This paper also discusses steps and strategies that can be taken to optimize the benefits of economic growth and investment in economic growth in Indonesia.

This research discussed the effect of population migration in Indonesia on the gap of economic growth in Indonesia. As for the variables that are influenced by economic growth and the independent variables or variables that influence are migration, recent migration, resign workers, and dependency ratios.

The data presented in this study were time series that displayed data for the last 20 years (1988 to Year 2019) with the variables.

The problem formulation of this research is as follows:

a. What are the conditions of migration in Indonesia from 1988 to 2019?

b. How is the influence between migration, recent migration, resign workers, the ratio of dependence on economic growth in North Sumatera

\section{METODE}

This research was a quantitative descriptive study. "According to Kuncoro (2013) descriptive research is data collection to test hypotheses or answer questions about the latest status of research subjects, the purpose of research was to develop and use mathematical models, theories and hypotheses related to other phenomena". This research is a combination of descriptive and quantitative.

The stages taken to analyze the data are as follows:

a. By conducting the preliminary study by examining previous studies that discuss population-related migration and economic growth

b. Collecting literature that focuses of the problem that becomes the main theme of the research.

c. Collecting data from each of the variables studied from the data source.

d. Process data from all data using SPSS software so that the results of the correlation of each independent variable to the dependent variable can be obtained. 
Papers are written based on analysis arguments from various data.

\section{RESULTS AND DISCUSSION}

\section{A. Migration in North Sumatera}

Migration is actually normal social phenomenon. The problems arise when migration is uncontrolled and has a social impact on the area, thereby affecting community development in an area as well as various series of risks that exist in the migration activity.

Such as migration in North Sumatra Province. The results of the Population Census from 1985 to 2020 showed that the number of outbound migration in North Sumatra Province increased drastically and was not balanced with the number of inbound migration that was relatively constant. In 2015, the number of out-migration in North Sumatra Province was recorded at $2,200,000$ people. Then in 2020, there was an increase in the number of outmigration by 2100,000 people.

\section{Table 1}

North Sumatra Population Composition

\begin{tabular}{lllll}
\hline Year & $\begin{array}{l}\text { Total } \\
\text { Population }\end{array}$ & $\begin{array}{l}\text { Inbound } \\
\text { Migration }\end{array}$ & $\begin{array}{l}\text { Outbound } \\
\text { Migration }\end{array}$ & Migration \\
\hline 1985 & 9.308 .460 & 485.212 & 562.987 & 77.775 \\
\hline 1990 & 10.256 .027 & 459.754 & 770.145 & 310.391 \\
\hline 1995 & 11.114 .667 & 552.545 & 1.000 .000 & 447.455 \\
\hline 2000 & 11.649 .655 & 447.978 & 1.300 .000 & 852.022 \\
\hline 2005 & 12.315 .928 & 447.365 & 1.300 .000 & 852.635 \\
\hline 2010 & 12.982 .204 & 521.879 & 2.300 .000 & 1.778 .121 \\
\hline 2015 & 13.937 .797 & 519.879 & 2.200 .000 & 1.680 .121 \\
\hline 2020 & 14.812 .123 & 509.789 & 2.500 .000 & 1.990 .211 \\
\hline
\end{tabular}

Processed Primary Data

This large population growth by year requires additional investment and facilities to support the people welfare such as education, health, economy and others. Migration activities are the movement of population from one area to another area with the purpose of settling in the area. Destination, migration is often defined as a relatively permanent movement from one area to another (the person is called a migrant).

Seen from the Table 1 of Population Census results for the year 1985 to 2020, it showed that the number of outbound migration in North Sumatra Province increased drastically and iwas not balanced with the number of in migration that was fairly constant. In 2015, the number of outbound migration in North Sumatra Province was recorded at $2,200,000$ people. Then in 2020 , it is estimated that there will be an increase in the number of outbound -migration as many as 2,500,000 people.

The large number of outbound migration is caused by several factors, namely economic factors, education, and the existence of community traditions. The majority of jobs available in North Sumatra Province are in the scope of the government and private sectors, the manpower with high level of education and adequate skills is needed. It causes North Sumatra Province people with low levels of education and inadequate skills, choose to migrate outside to find suitable jobs. It is supported by the tradition of the people of North Sumatra Province, the majority of which are Batak, where the activity of migrating becomes a hereditary habit for people of productive age.

In fact, this uncontrolled outbound -migration activity had a negative impact on development activities in North Sumatra Province. Based on the 20102015 Population Census, the Net Migration Rate (a figure that shows the difference between inbound and outbound migration per thousand population) in North Sumatra Province shows an alarming figure, namely 136.8. It showed that the activity of outgoing migration is large and not proportional to the number of incoming migration, making the Total Population, especially the productive age population in North Sumatra Province, decreasing.It causes the obstructed development in North Sumatera Province.

B. Characteristics of resign workersin North Sumatera

Resigning or stopping working from a company is one of the things that commonly happens in the world 
especially in big cities, resigning seems to have become something that is usually done by workers or employees. The large number of job vacancies in big cities becomes driving factor that is very easy for many workers to leave their jobs and move to other jobs.

Table 2

Number of resign workers in North Sumatra

\begin{tabular}{lllll}
\hline Year & Workforce & Working & $\begin{array}{l}\text { Unemployment } \\
\text { Level }\end{array}$ & $\begin{array}{l}\text { Resign } \\
\text { Worker }\end{array}$ \\
\hline 1985 & 3.463 .363 & 3.394 .159 & 3.46 & 69.204 \\
\hline 1990 & 3.948 .729 & 3.820 .329 & 3.25 & 128.400 \\
\hline 1995 & 4.567 .879 & 4.308 .890 & 4.56 & 213.064 \\
\hline 2000 & 5.283 .268 & 4.947 .539 & 6.72 & 335.729 \\
\hline 2005 & 5.803 .112 & 5.166 .132 & 10.98 & 636.980 \\
\hline 2010 & 6.617 .377 & 6.125 .571 & 7.43 & 491.806 \\
\hline 2015 & 6.391 .098 & 5.962 .304 & 6.71 & 412.455 \\
\hline 2020 & 7.195 .767 & 6.528 .431 & 6.75 & 441.097 \\
\hline
\end{tabular}

He labor force consists of the working age population who works or has a job but temporarily does not work and includes unemployment. Structurally, the workforce is part of the working age population that enters the workforce. The number of labor force each year has increased in line with the increase in the total population of working age. Seen from the Table 2 The increase in the working age population followed by an increase in the number of the workforce is a positive economic condition that shows the increase in the participation of the working age population in the labor market of $6,391,098$ people in 2015, then increased to $3,743,204$ people in 2009, then increased again. In year 2020 amounted to 7,195,767 people.

The population who worked for 35 years from 1985 to 2020 tends to fluctuate. The proportion of workers with business status assisted by household members continues to increase, as well as unpaid workers by years both in number and proportion. The population working in North Sumatra in 2015 consists of $5,962,304$ people and the increase in the year 2020 amounted to $6,528,431$ people.
Generally, the open unemployment rate in North Sumatra Province from Year 2010 to 2015 decreased. In 2010 there were 491,806 open unemployment people, decrease to 412,455 people in 2015 and in 2020, the increase of 441.097 was caused by the COVID 19 pandemic.

C. North Sumatra Dependency Ratio

The dependency ratio that is used to measure the amount of burden that must be borne by each productive age population on the unproductive population. Young residents under 15 years old are generally considered as unproductive residents because economically they are still dependent on their parents or other people who support them.

North Sumatra Regency dependency ratio in 1985-2020

Table 3

Total Dependency Ratio in North Sumatera

\begin{tabular}{lllllll}
\hline No & Year & $\begin{array}{l}\text { Total } \\
\text { Population } \\
\text { Age <15 } \\
\text { Years }\end{array}$ & $\begin{array}{l}\text { Total } \\
\text { Population } \\
\text { Age> 64 } \\
\text { Years }\end{array}$ & $\begin{array}{l}\text { Number of } \\
\text { Population } \\
\text { Unproductive } \\
\text { Age }\end{array}$ & $\begin{array}{l}\text { Total } \\
\text { Population } \\
15-64 \\
\text { Years }\end{array}$ & $\begin{array}{l}\text { Dependency } \\
\text { Ratio }\end{array}$ \\
\hline 1 & 1985 & 4668527 & 500733 & 5169260 & 5782817 & 89,3 \\
\hline 2 & 1990 & 4720249 & 506280 & 5226529 & 6371486 & 82,03 \\
\hline 3 & 1995 & 4311089 & 504296 & 4815385 & 6762232 & 71,21 \\
\hline 4 & 2000 & 3904777 & 418815 & 4323592 & 7152980 & 60,44 \\
\hline 5 & 2005 & 4090151 & 473269 & 4563420 & 7763258 & 58,78 \\
\hline 6 & 2010 & 4315441 & 504805 & 4820246 & 8161958 & 59,06 \\
\hline 7 & 2015 & 4436069 & 541017 & 541017 & 8809765 & 56,5 \\
\hline 8 & 2020 & 4666320 & 387865 & 5054185 & 9876967 & 51,17 \\
\hline
\end{tabular}

Based on Table 3, it explains that in North Sumatra Regency every two people of productive age must bear the burden of one non-productive population The dependency ratio (DR) is a value that shows how much productive population bears the unproductive population (Mantra, 2000). This ratio is obtained by comparing the total unproductive population (aged <15 years and $>64$ years) with the productive population (ages 15 - 64 years). This paper will analyze DR from 1985-2020.

The dependency ratio in North Sumatra always decreases by year (Table 3 ). It is because the total productive population continues to increase compared to the nonproductive 
population. In 1985, the worst DR score that North Sumatra has (worth DR). The dependency ratio can be an indicator of North Sumtera economic progress. It means that when the dependency ratio is high, the dependency ratio growth is influenced by the productive and unproductive total population. The total unproductive population is caused by a high population of children or a high population of elderly people. North Sumtera Province in 2020 had a high DR due to the high population of children. On the other hand, the population aged less than 15 was an asset that will be a productive population. It can be seen from Table 3 and the total productive population increased to reach a DR of 51.17 in 2020.

\section{Economic Growth in North Sumatra}

High and sustainable economic growth is the condition that is a necessity for the continuity of economic development and increasing welfare. The total population that increases every year must be accompanied by daily consumption needs that also increase each year. For that, a counterweight is needed in the form of the increase in income each year (Tambunan, 2009). In addition to consumption that is the demand side, population growth, when viewed from the supply side, also requires growth in employment opportunities (a source of income).

Table 4

Table of Economic Growth in North Sumatra

\begin{tabular}{|c|c|c|c|}
\hline Year & $\begin{array}{l}\text { GRDP Based on } \\
\text { Prices Applied }\end{array}$ & $\begin{array}{l}\text { GRDP Based on } \\
\text { Constant Price } \\
2000\end{array}$ & $\begin{array}{l}\text { Economic } \\
\text { Growth }\end{array}$ \\
\hline 1985 & 4.701 .779 & 25.817 .253 & 2,46 \\
\hline 1990 & 10.774 .791 & 38.582 .281 & 7.23 \\
\hline 1995 & 24.630 .520 & 59.679 .064 & 8.34 \\
\hline 2000 & 69.154 .112 & 69.154 .112 & 4.99 \\
\hline 2005 & 139.618 .310 & 87.897 .800 & 3.77 \\
\hline 2010 & 275700,250 & 118640,90 & 6,23 \\
\hline 2015 & 571722,010 & 440955,85 & 6,42 \\
\hline 2020 & 741192,690 & 512765,63 & 3,45 \\
\hline
\end{tabular}

During the peak period of the crisis, namely 1985-2000, the economy of North Sumatra experienced negative average growth of $6.42 \%$ per year. Then after the economic crisis had run for almost 10 years, economic growth had increased sharply even though it is still far below the growth before the economic crisis, namely in the 19992005 period that reached an average of $4.99 \%$ per year.

2. Multiple Linear Regression Model

Multiple linear regression model in analyzing the effect of migration, recent migration, dependency ratio on economic growth in North Sumatra. This study used secondary data on migration, recent migration, dependency ratios and economic growth. The following is in Table 4 that is the result of the output using the SPSS 20 software that showed the characteristics of the research variables on the dependent variable.

Table 5

Results of Multiple Linear Regression Calculation

\begin{tabular}{llllll}
\hline Coefficients $^{\mathbf{a}}$ & \multicolumn{2}{l}{} & & \\
\hline Model & \multicolumn{2}{l}{$\begin{array}{l}\text { Unstandardized } \\
\text { Coefficients }\end{array}$} & $\begin{array}{l}\text { Standardized } \\
\text { Coefficients }\end{array}$ & t & Sig. \\
\cline { 2 - 5 } & $\mathrm{B}$ & $\begin{array}{l}\text { Std. } \\
\text { Error }\end{array}$ & Beta & & \\
\hline (Constant) & -155.247 & 34.440 & & -4.508 & .000 \\
\hline M & 6.196 & 2.317 & 1.600 & 2.674 & .012 \\
\hline MR & 5.048 & 5.984 & 1.981 & 2.515 & .017 \\
\hline PR & 3.922 & 1.902 & 1.739 & 2.063 & .048 \\
\hline RD & 1.408 & 1.071 & 3.251 & 5.774 & .000 \\
\hline
\end{tabular}

a. Dependent Variable: PE

The value of the equation in the multiple regression model can be interpreted as follows:

1. The constant value $\beta 0=-155,247$. This figure explains that the economic growth in North Sumatra will $-155,002$ if other factors are equal to zero.

2. The regression coefficient of the migration rate variable $(X 1)=6.196$. The coefficient was positive, so it can be explained that if the migration rate increases by one level or one year, the economic growth rate in North Sumatra increased by 6,196 times.

3. Recent migration rate variable regression coefficient $(\mathrm{X} 2)=5.048$. The coefficient was positive, it can be explained that if the recent migration rate increased by one level or one 
year, the rate of economic growth in North Sumatra had increased by 5,048 times.

4. Recent regression coefficient for variable rate of employment $(\mathrm{X} 3)=$ 3,922 . The coefficient was positive, it can be explained that if the recent employment rate increased by one level or one year, the economic growth rate in North Sumatra increased 3.922 times.

5. The regression coefficient of the variable level of dependency ratio (X3) $=1.408$. The coefficient was positive, it can be explained that if the level of dependency ratio increased by one level or one year, the rate of economic growth in North Sumatra increased by 1,408 times.

\section{A. Classic assumption test}

1. Normality Test

For the OLS application to the classical linear model was assumed that the probability distribution of the error term. The assumption made that the confounding factor has the expected mean value is the same as the uncorrelated nola and has constant variance.There are several tests to determine whether the disturbance factor. One of them is by looking at its probability value.

2. Results of Normality Test

Table 6

Test Normality

\begin{tabular}{|c|c|c|c|c|c|c|}
\hline \multicolumn{7}{|c|}{ One-Sample Kolmogorov-Smirnov Test } \\
\hline \multirow[t]{2}{*}{$\mathrm{N}$} & & $\mathrm{PE}$ & $M$ & MR & PR & RD \\
\hline & & 36 & 36 & 36 & 36 & 36 \\
\hline \multirow[t]{2}{*}{$\begin{array}{l}\text { Normal } \\
\text { Parameters }\end{array}$} & Mean & 5.63083 & 5.87778 & 5.06639 & 5.46139 & 6.57 \\
\hline & $\begin{array}{l}\text { Std. } \\
\text { Deviation }\end{array}$ & $1.440255 \mathrm{E} 0$ & .371915 & .093874 & 271284 & \\
\hline \multirow[t]{3}{*}{$\begin{array}{l}\text { Most } \\
\text { Extreme } \\
\text { Differences }\end{array}$} & Absolute & .073 & .135 & .144 & .195 & .260 \\
\hline & Positive & .058 & .128 & .085 & .106 & .260 \\
\hline & Negative & -.073 & -.135 & -.144 & -.195 & -.10 \\
\hline \multicolumn{2}{|c|}{ Kolmogorov-Smirnov Z } & .437 & .810 & .864 & 1.172 & 1.56 \\
\hline \multicolumn{2}{|c|}{ Asymp. Sig. (2-tailed) } & .991 & .529 & .445 & .128 & .015 \\
\hline
\end{tabular}

Based on the results of the output above the probability value was $0.991>0.05$, the hypothesis which states that the residuals is normally distributed cannot be rejected.

3. Multicollinearity Test
A model is said to multicollinearity when there is a perfect linear relationship between some or all of the independent variables of a regression model (Gujarati). As a result, it will be difficult to see the effect of the explanatory variables on the variables described. There are many procedures to detect whether our data is affected by multicollinearity or not. The simplest way is through correlation between redictors. A correlation between redictors is high (above 0.8 or 0.9 ), it showed that data was multi-colic (Baron, Field, \& Schuller, 2000).

Table 7 Test multicolinearity

\begin{tabular}{|c|c|c|}
\hline \multicolumn{3}{|l|}{ Coefficients $^{a}$} \\
\hline \multirow[t]{2}{*}{ Model } & \multicolumn{2}{|c|}{ Collinearity Statistics } \\
\hline & Tolerance & VIF \\
\hline \multicolumn{3}{|l|}{ (Constant) } \\
\hline $\mathrm{M}$ & .040 & 5.070 \\
\hline MR & .044 & 5.653 \\
\hline PR & .061 & 8.986 \\
\hline RD & .045 & 7.206 \\
\hline a. Dependent V & & \\
\hline
\end{tabular}

Based on the output results above, all the predictor values above were less than 0.8 , it can be concluded that the data were free from multicollinearity.

4. Autocorrelation Test

Autocorrelation is defined as the correlation between members of a series of observations that are ordered according to time or space to test the 570.8sumption that the data must be free, $48 d a$ anely in the sense that data for a certain period does not affect the data from the previous period. To determine the autocorrelation, it can be seen .103from the Durbin Watson value. The model is free from autocorrelation if the calculated Durbin Watson value is located in an area where there is no autocorrelation seen from the dLa dU and 4 - dU and 4 - dL values.

5. Basic of Autocorrelation Test 
If the durbin-watson value is less than $\mathrm{dL}$ or greater than $(4-\mathrm{dL})$ then there is autocorrelation.

1) If the durbin-watson value lies between $\mathrm{dU}$ and (4-dU), then there is no autocorrelation.

2) If the durbin-watson value lies between $\mathrm{dL}$ and $\mathrm{dU}$ or between (4$\mathrm{dU}$ ) and (4-dL), it will not result a definite conclusion.

Table 8

Test Autocorrelation

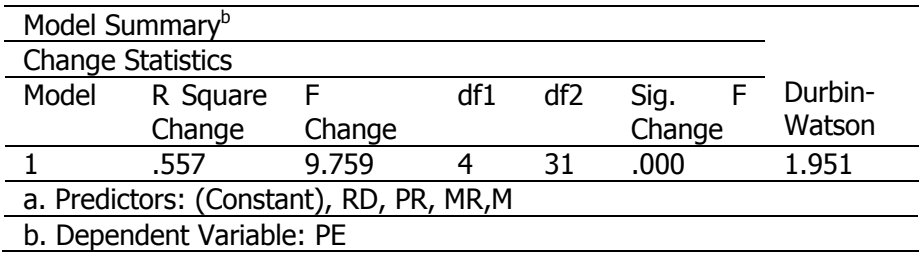

Based on the output above, it is known that the DW (Durbin Watson) value was 0.451 . Furthermore, we will compare this value with the value of the DW Table with a significance of $5 \%$, it is known that the number of data was $\mathrm{N}=36$ and the number of independent variables $K=4$, so the value of du (upper limit) was 1.6505. This DW value of 1.951 was greater than the upper limit (du) of 1.6505 and the DW value of 1.954 was less than (4 -du) $4-1.6505=2.3495$. It can be concluded that there was no autocorrelation

\section{B. Statistics Test}

The statistical F-test is a simultaneous statistical test to determine whether all independent variables (migration, recent migration, resign workersand dependency ratios) entered into the regression model jointly affect the dependent variable (Economic Growth) in North Sumatra.

Table 10

Test F

\begin{tabular}{llllll}
\hline ANOVA $^{\mathbf{b}}$ & \multicolumn{1}{l}{ of } & $\begin{array}{l}\text { Mean } \\
\text { Model }\end{array}$ & $\begin{array}{l}\text { Sum of } \\
\text { Squares }\end{array}$ & F & Sig. \\
\hline Regression & 40.466 & 4 & 10.117 & 9.759 & $.000^{\text {a }}$ \\
\hline Residual & 32.135 & 31 & 1.037 & & \\
\hline Total & 72.602 & 35 & & & \\
\hline a. Predictors: (Constant), RD, PR, MR,M & & \\
\hline
\end{tabular}

b. Dependent Variable: PE

In the table above, it can be seen that the F-statistic Probability value = 9,759 . According to the F-statistical criterion, if the probability F-statistic was 9,759 $<0.05$ then $\mathrm{HO}$ was rejected, it means that the independent variables (migration, recent labor migration and dependency ratio) together had a significant and significant effect on the dependent variable (economic growth) in North Sumatra. The regression model obtained was good for estimating economic growth in North Sumatra.

C. T-Test

Partial test ( $t$ test) is seen from the significance of the $t$-value. The $t$ test is used to see the significance of the effect of the independent variable on the dependent variable individually. To perform the $t$ test by means of Quick Look, namely by looking at the probability value and the degree of confidence determined in the study. If the probability value <the degree of confidence determined in the study, then an independent variable individually affects the dependent variable. The following table t statistics test.

\begin{tabular}{llll} 
& & $\begin{array}{l}\text { Table 9 } \\
\text { T-Test }\end{array}$ \\
\hline Coefficients $^{\mathbf{a}}$ & & \\
\hline Model & $\mathrm{T}$ & Sig. & $\begin{array}{l}\text { Standar } \\
\text { Prob }(\mathrm{a})\end{array}$ \\
\hline (Constant) & -4.508 & .000 & $5 \%(0,05)$ \\
\hline $\mathrm{X} 1$ & 5.774 & .000 & $5 \%(0,05)$ \\
\hline $\mathrm{X} 2$ & 2.674 & .012 & $5 \%(0,05)$ \\
\hline $\mathrm{X} 3$ & 2.063 & .048 & $5 \%(0,05)$ \\
\hline $\mathrm{X} 4$ & 2.515 & .017 & $5 \%(0,05)$ \\
\hline a. Dependent Variable: $\mathrm{Y}$ & & \\
\hline \multicolumn{4}{l}{}
\end{tabular}

Statistical t test for labor variables. The test for this $t$ test is if the probability value (significance) <alpha then there was a significant influence between the independent variables (migration, recent labor migration and the dependency ratio) on the dependent variable (economic growth). Vice versa, if the probability value (significance) $>$ alpha then there was no significant effect between the 
independent variable on the dependent variable. Based on the table, it can be seen that the probability value (significance) is $\mathrm{X} 1=0.000, \mathrm{X} 2=0.012$, $X 3=0.048$ and $X 4=0.017$. Because the probability value (significance) <alpha (a $=0.05)$, all variables affect economic growth in the North Sumatra.

\section{CONCLUSION}

This study discussed the phenomenon of economic growth influenced by some variables.

1. Seeing the magnitude of the effect of migration on economic growth, the government must control and pay special attention to the population that migrates into and out of the province of North Sumatra both in quality and quantity.

2. The magnitude of recent migration can indicate that resign workersshow that economic motives are the main driver of population movement. It shows that the government must expand job opportunities throughout North Sumatra.

3. resign workerscan be used as an alternative to equal distribution of the working age population which in the end it is hoped that all regions in North Sumatra can increase economic growth.

4. Dependency Ratio by stating that individuals prefer to be optimal in increasing the number of workers in North Sumatra by utilizing existing components in boosting the economy.

\section{REFERENCES}

Baron, Stephen, Field, John, \& Schuller, Tom. (2000). Social capital: Critical perspectives. OUP Oxford. Google Scholar

Bloom, David E., Canning, David, \& Sevilla, Jaypee. (2004). The effect of health on economic growth: a production function approach. World Development, 32(1), 1-13. Google Scholar

Bloom, David E., \& Williamson, Jeffrey G.
(1998). Demographic transitions and economic miracles in emerging Asia. The World Bank Economic Review, 12(3), 419-455. Google Scholar

Choudhry, Misbah T., \& Elhorst, J. Paul. (2010). Demographic transition and economic growth in China, India and Pakistan. Economic Systems, 34(3), 218-236. Google Scholar

Golley, Jane, \& Zheng, W. E. I. (2015). Population dynamics and economic growth in China. China Economic Review, 35, 15-32. Google Scholar

Kuncoro, Mudrajad. (2013). Economic geography of Indonesia: can MP3EI reduce inter-regional inequality. South East Asian Journal of Contemporary Business, Economics, and Law, 2(2), 17-33. Google Scholar

Kuznets, Simon. (1967). Population and economic growth. Proceedings of the American Philosophical Society, 111(3), 170-193. Google Scholar

Liu, Hu Chen, Liu, Long, \& Liu, Nan. (2013). Risk evaluation approaches in failure mode and effects analysis: A literature review. Expert Systems with Applications, 40(2), 828-838. Google Scholar

Mantra, Ida Bagus. (2000). Demografi umum. Pustaka Pelajar. Google Scholar

Mettler, Everett, Massey, Christine M., \& Kellman, Philip J. (2016). A comparison of adaptive and fixed schedules of practice. Journal of Experimental Psychology: General, 145(7), 897. Google Scholar

Peng, Xizhe, \& Cheng, Yuan. (2005). Demographic Bonus and the Impact of Migration: The Case of Shanghai, The International Centre for the Study of East Asian Development. Kitakyushu, Working Paper Series. Google Scholar 
Tambunan, Tulus. (2009). Women entrepreneurship in Asian developing countries: Their development and main constraints. Journal of Development and Agricultural Economics, 1(2), 27-40. Google Scholar

Todaro, Michael, \& Smith, Stephen. (2012). Economic Development. 11th. New York, NY: Pearson Education Inc. Accessed January, 27, 2017. Google Scholar

\section{Copyright holder:}

Zulkarnain Nasution and Muhammad Ali Al Ihsan (2021)

First publication right:

Journal of Social Science (JSS)

This article is licensed under:

(c) (i) (2) 